\title{
Antimicrobial activity of denture adhesive associated with Equisetum giganteum- and Punica granatum-enriched fractions against Candida albicans biofilms on acrylic resin surfaces
}

Nara Ligia Martins Almeida, Luiz Leonardo Saldanha, Rafaela Alves da Silva, Karen Henriette Pinke, Eliane Ferraz da Costa, Vinicius Carvalho Porto, Anne Lígia Dokkedal \& Vanessa Soares Lara

To cite this article: Nara Ligia Martins Almeida, Luiz Leonardo Saldanha, Rafaela Alves da Silva, Karen Henriette Pinke, Eliane Ferraz da Costa, Vinicius Carvalho Porto, Anne Lígia Dokkedal \& Vanessa Soares Lara (2018) Antimicrobial activity of denture adhesive associated with Equisetum giganteum- and Punica granatum-enriched fractions against Candida albicans biofilms on acrylic resin surfaces, Biofouling, 34:1, 62-73, DOI: 10.1080/08927014.2017.1407408

To link to this article: https://doi.org/10.1080/08927014.2017.1407408

View supplementary material $\asymp$

$$
\text { 曲 Published online: } 18 \text { Dec } 2017 .
$$

Submit your article to this journal एᄌ

Џ Article views: 246

View Crossmark data $\nearrow$ 


\title{
Antimicrobial activity of denture adhesive associated with Equisetum giganteum- and Punica granatum-enriched fractions against Candida albicans biofilms on acrylic resin surfaces
}

\author{
Nara Ligia Martins Almeidaa ${ }^{a}$ Luiz Leonardo Saldanha ${ }^{b, c}$, Rafaela Alves da Silva ${ }^{a}$ (D), Karen Henriette Pinke ${ }^{a}$, Eliane \\ Ferraz da Costaa ${ }^{a}$ Vinicius Carvalho Portod ${ }^{\text {DD }}$, Anne Lígia Dokkedalc and Vanessa Soares Lara ${ }^{\mathrm{a}}$ (D) \\ ${ }^{a}$ Department of Surgery, Stomatology, Pathology and Radiology, Bauru School of Dentistry, University of São Paulo, Bauru, Brazil; bepartment \\ of Botany, Institute of Biosciences, São Paulo State University (UNESP), Botucatu, Brazil; 'Department of Biological Sciences, Faculty of Sciences, \\ São Paulo State University (UNESP), Bauru, Brazil; ' Department of Prosthodontics and Periodontics, Bauru School of Dentistry, University of São \\ Paulo, Bauru, Brazil
}

\begin{abstract}
Candida biofilms adhere to the internal surface of removable dentures, which is an etiological factor in the pathogenesis of denture stomatitis (DS). Adhesive materials are used at the base of maxillary complete dentures to improve their retention and chewing qualities. This article reports the antimicrobial activity of the enriched fractions of Equisetum giganteum and Punica granatum incorporated into a denture adhesive against $C$. albicans biofilm. The biofilms were induced on the surface of heat-cured acrylic resin specimens that were previously treated with a mixture of adhesive/herb extracts. The antimicrobial activity was evaluated by CFU counts, XTT reduction, and SEM and CLSM analysis. Both herb extracts amplified the anti-biofilm action of the adhesive on the acrylic resin by up to $12 \mathrm{~h}$. Therefore, when these extracts were combined with COREGA ${ }^{\oplus}$, they played a collaborative and innovative role in biofilm control and can be considered alternatives for temporary use in the treatment and/or prevention of DS.
\end{abstract}

ARTICLE HISTORY

Received 12 April 2017

Accepted 7 November 2017

\section{KEYWORDS}

Denture stomatitis; herbal medicines; pomegranate; giant horsetail; anti-biofilm; alternative therapy

\section{Introduction}

One of the most prevalent lesions in complete removable denture wearers, denture stomatitis (DS), is a chronic disease that can be characterized by localized or generalized inflammation of the oral mucosa, and is considered difficult to treat due to its multifactorial etiology (Huang and Wu 2005). Although many causal factors are involved in this disease (Budtz-Jorgensen 1978), most studies have indicated that Candida albicans infection represents the main etiological factor (Budtz-Jorgensen and Bertram 1970; Arendorf and Walker 1987; Loster et al. 2016; Aslanimehr et al. 2017). Candida species have the capacity to adhere to and colonize the heat-cured acrylic resin of the denture base (Budtz-Jorgensen 1990; Chau et al. 1995), which is often rough and microporous, thereby facilitating the invasion of microorganisms (Bollen et al. 1997). The growth of Candida spp. in mycelial form allows this fungus to develop inside the grooves formed on the microporous resin, protecting itself from internal removal forces, such as the self-cleaning effect of saliva and brushing (Samaranayake et al. 1980). Moreover, the internal surface can deteriorate as a result of oral hygiene, presenting roughness values well above $0.2 \mu \mathrm{m}$, making it susceptible to contamination and aiding the process of biofilm formation (Bollen et al. 1997). Therefore, in association with proper oral and denture hygiene, DS treatment may involve the prescription of topical and/or systemic conventional antifungal agents (Bueno et al. 2015). Due to their high oral bioavailability and easy access to conventional antifungal agents, medications such as nystatin and fluconazole have been widely used to treat pathologies where C. albicans is the main causal factor ( $\mathrm{Ng}$ et al. 2017; Singh et al. 2017).

However, this approach has limitations, since systemic antifungal agents, such as azoles, and local antifungal agents, such as various nystatin-based formulations, cannot effectively act on the inner surface of contaminated dentures (Barbeau et al. 2003; Bueno et al. 2015; Lima et al. 2016), since biofilms are highly resistant to conventional treatments. Additionally, topical antifungal agents have side effects, such as allergic reactions and nausea due

CONTACT Vanessa Soares Lara vanessa@fob.usp.br

4 The supplemental material for this article can be accessed at https://doi.org/10.1080/08927014.2017.1407408

(C) 2017 Informa UK Limited, trading as Taylor \& Francis Group 

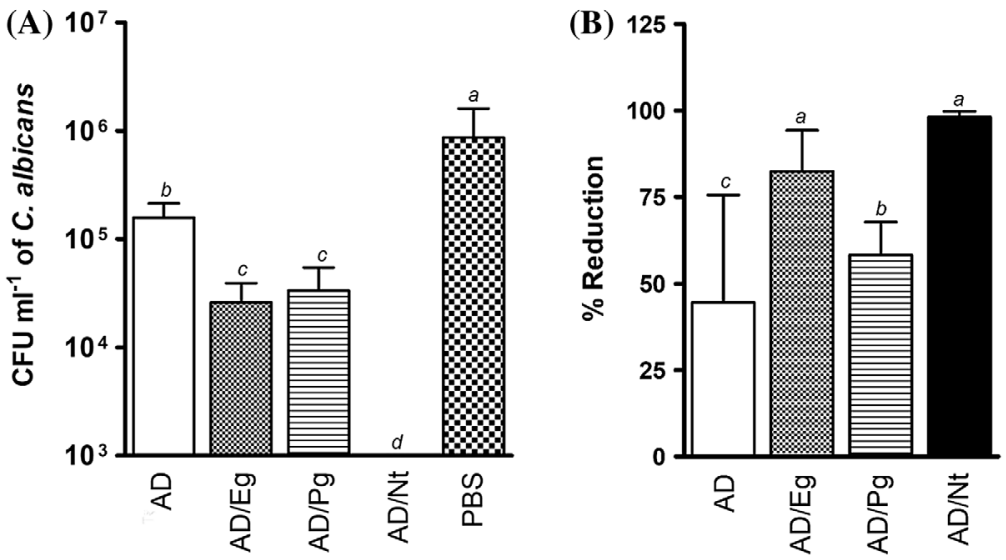

(C)

(D)

\begin{tabular}{ccc}
\hline Groups & Biofilm mass $\left(\boldsymbol{\mu m}^{\mathbf{3}}\right)$ & Viable/ nonviable (\%) \\
\hline $\mathbf{A D}$ & $14,195 \pm 18,121$ & $70.5 / 28.7$ \\
$\mathbf{A D} / \mathbf{E g}$ & $3,036.5 \pm 3,232.1$ & $44.2 / 55.7$ \\
$\mathbf{A D} / \mathbf{P g}$ & $6,334.6 \pm 3,261$ & $34.5 / 65.1$ \\
$\mathbf{A D} / \mathbf{N t}$ & $3,368.8 \pm 275$ & $15.3 / 84.9$ \\
$\mathbf{P B S}$ & $29,950.3 \pm 22,610.7$ & $96.6 / 3.2$ \\
\hline
\end{tabular}

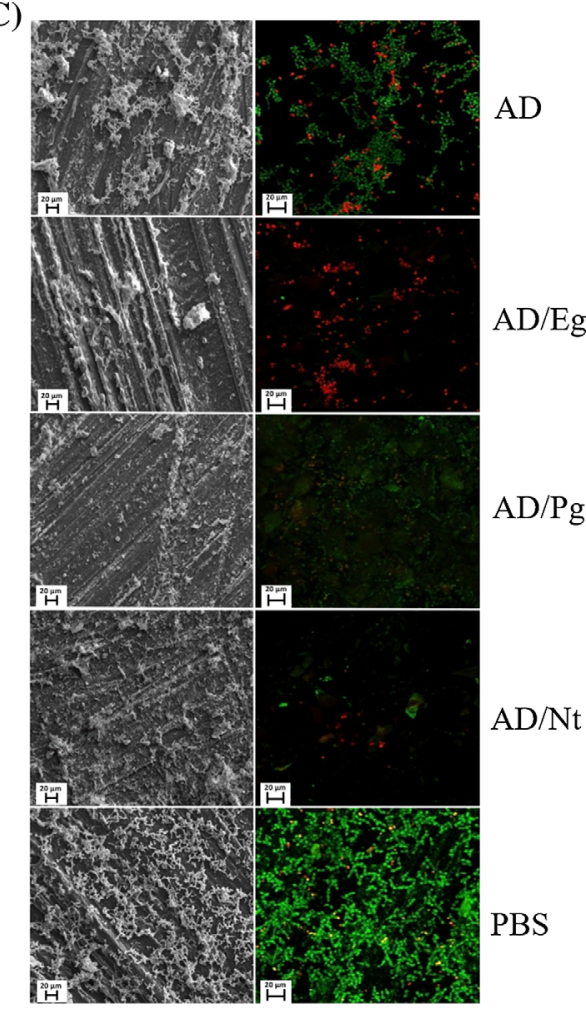

Figure 1. Analysis of $C$. albicans biofilm after development for $\mathbf{3} \mathbf{h}$ on surfaces treated with COREGA ${ }^{\oplus}$ powder alone

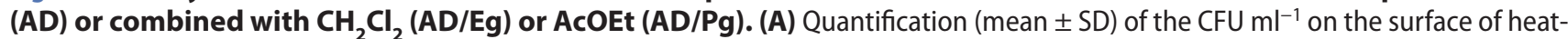
cured acrylic resin specimens, according to the Mann-Whitney test. (B) Percentage (mean \pm SD) reduction in the metabolic activity of $C$. albicans biofilms by the XTT reduction assay, according to a two-way analysis of variance (ANOVA), followed by a post hoc Tukey HSD. (C) SEM images of the C. albicans biofilm microarchitecture (first column) and CLSM images showing the distribution of viable (green) and nonviable (red) fungal cells (second column) (scale bars $20 \mu \mathrm{m}$ ). (D) Mean \pm SD of the biofilm mass ( $\mu \mathrm{m}^{3}$ ) and mean percentage (\%) of viable and nonviable cells. The data obtained from CLSM images were analyzed by the Biolmage software program. For all evaluations, untreated specimens (PBS) or specimens treated with nystatin (AD/Nt) were the controls, and three independent experiments were performed in triplicate ( $n=90-\mathbf{A}$ and $\mathbf{B})$ or in duplicate per group $(n=10-\mathbf{C}$ and $\mathbf{D})$. Different letters represent $p \leq 0.05$.

to their extremely unpleasant taste (Terrell 1999), while systemic antifungal agents have undesirable secondary effects, such as hepatotoxicity (Heinemann et al. 1997) and nephrotoxicity (Varlam et al. 2001).

Topically, it is difficult to maintain an effective drug concentration at the infected surfaces and tissues due to salivary flow, the tongue and swallowing movements, which rapidly dissolve and eliminate the drug from the oral cavity (Bueno et al. 2015). Thus, the continued use of biocompatible adhesive materials associated with compounds that have anti-Candida action, even for a limited period of time, may be very beneficial in preventing DS or contributing to the treatment of this disease.

Therefore, as they are a new source of diverse and potent actives, herbal medicines have proven to be an effective and innovative therapeutic option for treatment and/or prevention of DS. Reports in the literature have shown that plant extracts have antimicrobial activity against oral pathogens, particularly against $C$. albicans (Koo et al. 2000; Vasconcelos et al. 2006; Samet et al. 2007; Braga et al. 2008; Endo et al. 2010). The crude extract (EtOH $70 \%$ ) of Equisetum giganteum L. has been shown to be beneficial against the formation of $C$. albicans biofilms. This herb has shown antimicrobial activity against $C$. albicans, Staphylococcus aureus (S. aureus) and Escherichia coli (E. coli), anti-adherent activity against $C$. albicans on the surface of polymerized acrylic resin and anti-inflammatory action on human monocytes activated by C. albicans. This antimicrobial activity is related to the presence of secondary metabolites, such as flavonoids, found in the $70 \%$ $\mathrm{EtOH}$ fraction of E. giganteum. Additionally, this herb has not negatively affected the viability of human epithelial cells or monocytes in the human palate (Alavarce et al. 2015).

The antimicrobial activity of Punica granatum L. has been widely investigated (Endo et al. 2012; Bakkiyaraj et al. 2013; Labsi et al. 2016). The crude extract of $P$. granatum appears to be able to inhibit microbial adhesion. Researchers have claimed that oral bacterial biofilms and C. albicans were sensitive to this extract. Considering the 


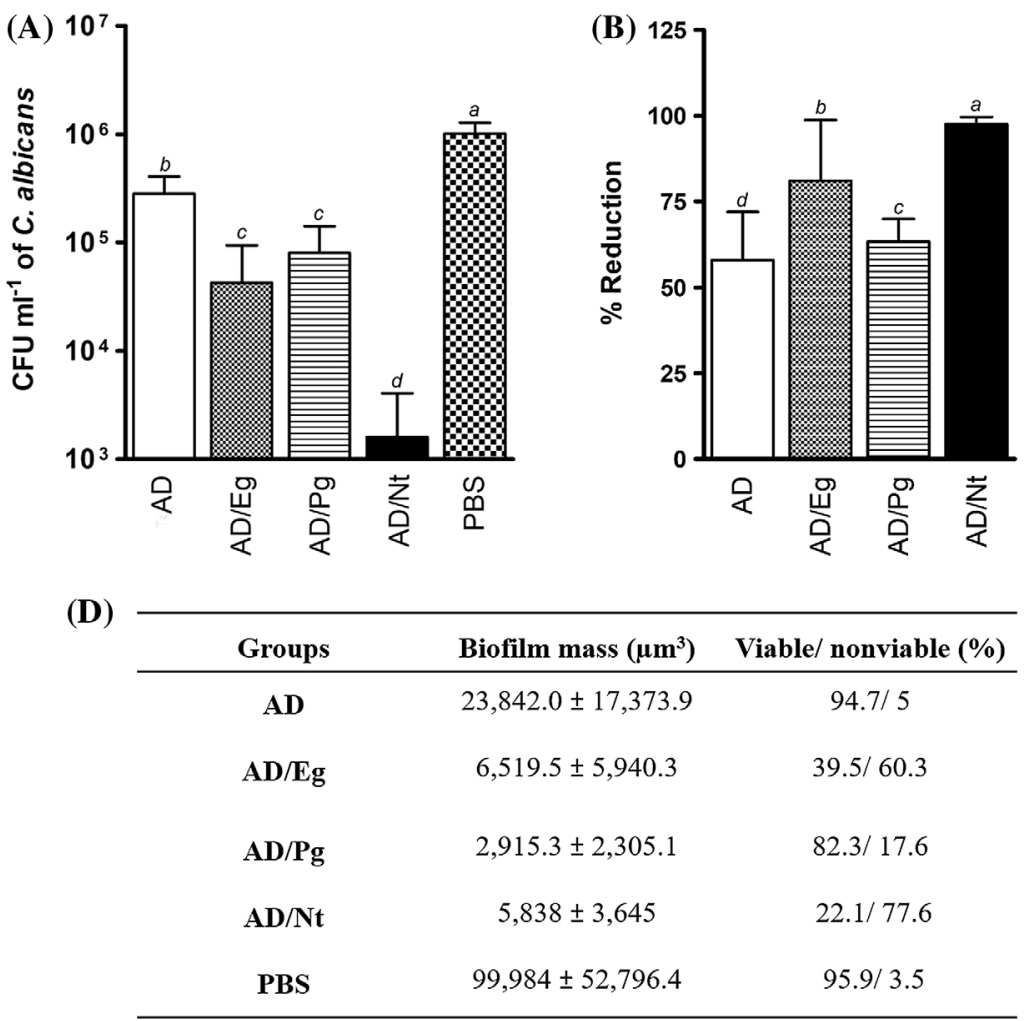

(C)

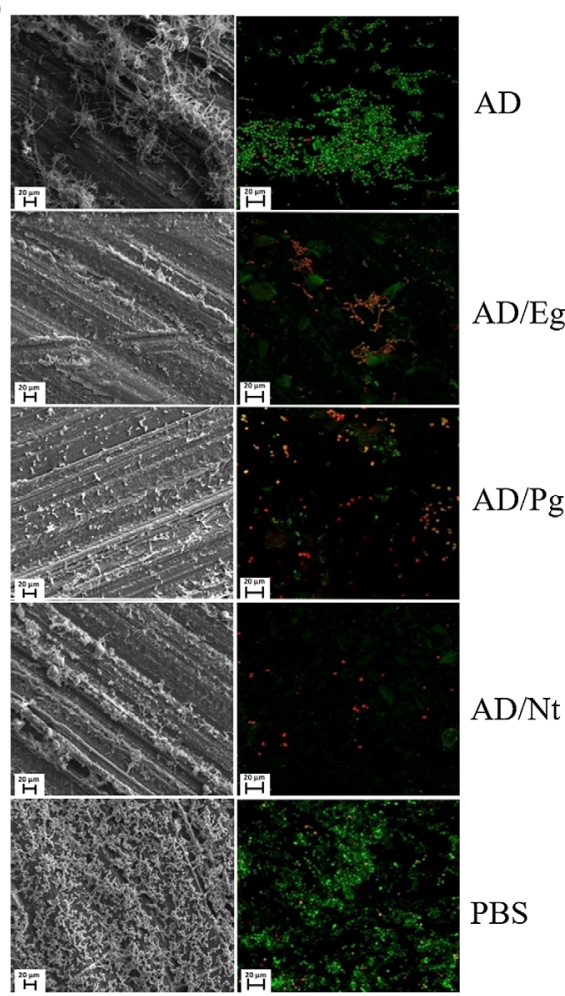

Figure 2. Analysis of the $C$. albicans biofilm after development for $6 \mathrm{~h}$ on the surface treated with COREGA ${ }^{\oplus}$ powder alone (AD), or combined with $\mathrm{CH}_{2} \mathrm{Cl}_{2}$ (AD/Eg) or AcOEt (AD/Pg). (A) Quantification (mean $\pm \mathrm{SD}$ ) of the $\mathrm{CFU} \mathrm{ml}^{-1}$ on the surface of heat-cured acrylic resin specimens, according to the Mann-Whitney test. (B) Percentage (mean \pm SD) reduction in the metabolic activity of the C. albicans biofilm, by the XTT reduction assay, according to two-way analysis of variance (ANOVA), followed by a post hoc Tukey HSD. (C) SEM images of the C. albicans biofilm microarchitecture (first column) and CLSM images showing the distribution of viable (green) and nonviable (red) fungi cells (second column) (scale bars $20 \mu \mathrm{m}$ ). (D) Mean \pm SD of the biofilm mass $\left(\mu \mathrm{m}^{3}\right.$ ) and mean percentage (\%) of viable and nonviable cells. The data obtained from CLSM images were analyzed by the Biolmage software program. For all evaluations, untreated specimens (PBS) or specimens treated with nystatin (AD/Nt) were the controls, and three independent experiments were performed in triplicate $(n=90-\mathbf{A}$ and $\mathbf{B})$ or in duplicate per group $(n=10-\mathbf{C}$ and $\mathbf{D})$. Different letters represent $p \leq 0.05$.

gaps in knowledge about the mechanism of action and the bioactive principles of these microorganisms, tannins, which are the main polyphenols of the P. granatum extract, are believed to act on cellular metabolism through the cell walls. These compounds bind to the cell wall, cross this structure and interfere with the production of proteins and enzymes responsible for microbial adhesion (Vasconcelos et al. 2006). Thus, these herbal medicines could play an important role in the treatment and/or prevention of DS (Casaroto and Lara 2010; Alavarce et al. 2015). Overall, these herbal medicines contain compounds with antimicrobial activity, and, in recent years, there has been growing interest in identifying them (Endo et al. 2010; Anibal et al. 2013).

Considering that DS is mainly associated with the fungus C. albicans, it is important and crucial to create biocompatible antifungal therapeutic alternatives with new antimicrobial active principles to which the fungus C. albicans does not yet have resistance. For example, denture adhesives have been associated with antimicrobial components, such as hexachlorophene, sodium tetraborate, sodium borate and ethanol (Grasso 2004; Pradies et al. 2009). These materials are provisionally used at the base of the dentures and are recommended for use by complete removable denture wearers, particularly for maxillary dentures, to improve chewing quality, because they allow more efficient grinding of the ingested food by increasing denture retention on the supporting mucosa (Folse 2004; Sato et al. 2008; Bartlett et al. 2013). In addition, the use of denture adhesive results in decreased pressure on the supporting tissues, distributing occlusal forces and reducing localized pressure at any one point. As a result, this minimizes tissue trauma, minimally irritating the mucosa, and especially lowering the risk of developing DS (Tarbet et al. 1980; Perez et al. 1985; Papadiochou et al. 2015).

The combination of denture adhesives and herbal medicines may be a useful, effective and a complementary alternative for the treatment of DS, in addition to enhancing 

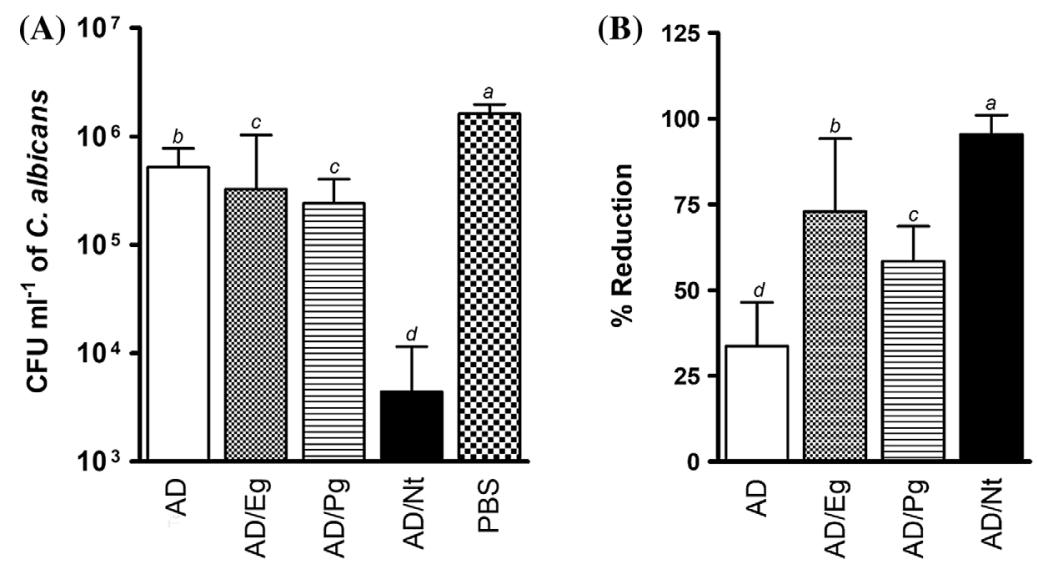

(C)

(D)

\begin{tabular}{ccc}
\hline Groups & Biofilm mass $\left(\boldsymbol{\mu m}^{\mathbf{3}}\right)$ & Viable/ nonviable (\%) \\
\hline AD & $14,396.4 \pm 3,288$ & $68.3 / 31.1$ \\
AD/Eg & $3,602.7 \pm 2,870$ & $71.1 / 28.6$ \\
AD/Pg & $21,747 \pm 13,992.9$ & $72 / 25.7$ \\
AD/Nt & $2,393.2 \pm 965$ & $85 / 14.4$ \\
PBS & $140,304.8 \pm 69,946$ & $97.8 / 2$ \\
\hline
\end{tabular}

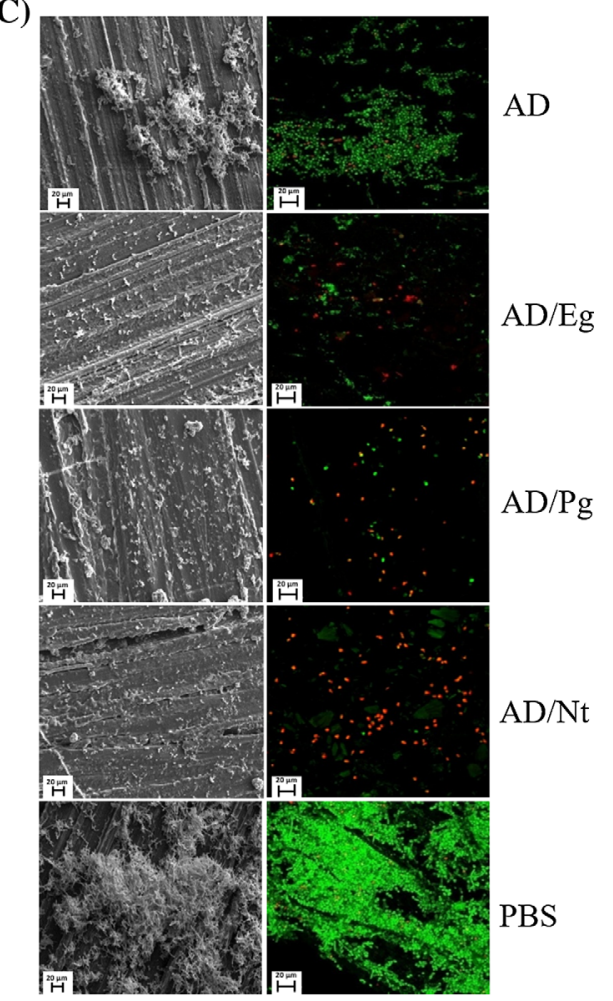

Figure 3. Analysis of the $C$. albicans biofilm after development for $12 \mathrm{~h}$ on a surface treated with COREGA ${ }^{\bowtie}$ powder alone (AD), or combined with $\mathrm{CH}_{2} \mathrm{Cl}_{2}$ (AD/Eg) or AcOEt (AD/Pg). (A) Quantification (mean $\pm \mathrm{SD}$ ) of the $\mathrm{CFU} \mathrm{ml}^{-1}$ on the surface of heat-cured acrylic resin specimens, according to the Mann-Whitney test. (B) Percentage (mean \pm SD) reduction in the metabolic activity of the C. albicans biofilm by the XTT reduction assay, according to a two-way analysis of variance (ANOVA), followed by post hoc Tukey HSD. (C) SEM images of the C. albicans biofilm microarchitecture (first column) and CLSM images showing the distribution of viable (green) and nonviable (red) fungal cells (second column) (scale bars $20 \mu \mathrm{m}$ ). (D) Mean \pm SD of the biofilm mass $\left(\mu \mathrm{m}^{3}\right.$ ) and mean percentage (\%) of the viable and nonviable cells. The data obtained from CLSM images were analyzed by the Biolmage software program. For all the evaluations, untreated specimens (PBS) or specimens treated with nystatin (AD/Nt) were the controls, and three independent experiments were performed in triplicate $(n=90-\mathbf{A}$ and $\mathbf{B})$ or in duplicate per group $(n=10-\mathbf{C}$ and $\mathbf{D})$. Different letters represent $p \leq 0.05$.

denture retention and comfort in the mouth. Considering these aspects, this study evaluated whether the incorporation of enriched fractions of E. giganteum (Equisetaceae) or P. granatum (Lythraceae) into the denture adhesive powder (COREGA ${ }^{\oplus}$ powder, GlaxoSmithKline Brazil Ltda, Rio de Janeiro, Brazil) formulation on the acrylic resin surface would amplify antimicrobial action against C. albicans biofilms.

\section{Materials and methods}

\section{Plant material and preparation of the extract}

The aerial parts of E. giganteum were collected in November 2014 at 'Jardim Botânico Municipal de Bauru', SP, Brazil $\left(22^{\circ} 20^{\prime} 30^{\prime \prime} \mathrm{S}, 49^{\circ} 00^{\prime} 30^{\prime \prime} \mathrm{W}\right)$. Voucher specimens were included in the Herbarium collection of UNESP (UNBA) in Bauru at São Paulo State University 'Júlio de Mesquita Filho' under code number 5795 . The fresh material (aerial parts) was dried in an air circulating oven at $45^{\circ} \mathrm{C}$ until it was completely dry $(2.9 \mathrm{~kg})$. The extract was obtained by percolation in $70 \%$ ethanol (EtOH: $\left.\mathrm{H}_{2} \mathrm{O} 7: 3 \mathrm{v} \mathrm{v}^{-1}\right)$ at room temperature. The solvent was evaporated, and the extract was lyophilized, yielding $41 \mathrm{~g}$ (8.3\%) of crude hydroalcoholic extract $(70 \% \mathrm{EtOH})$ of E. giganteum.

The P. granatum fruits were purchased at the 'Boa Fruta' Fruit and Seedling Distributor Supermarket in November 2014. The fruit was cultivated in Petrolina, Pernambuco, Brazil $\left(9^{\circ} 46^{\prime} 30^{\prime \prime} \mathrm{S}, 24^{\circ} 21^{\prime} 30^{\prime \prime} \mathrm{W}\right)$. Pruning was carried out every two months by scaling, and batch drip irrigation was provided. An aliquot of fresh fruit peels $(920 \mathrm{~g})$ was completely dried in an air circulation oven at $45^{\circ} \mathrm{C}$. The hydroalcoholic extract was obtained by percolation through the dried material (400 g) at room temperature. After removing the solvent, the P. granatum crude hydroalcoholic extract $(70 \% \mathrm{EtOH})$ from the fruit peels was lyophilized, yielding $52 \mathrm{~g}$ (13\%). 


\section{E. giganteum or P. granatum enriched fractions by liquid-liquid extraction (LLE)}

An aliquot of $2 \mathrm{~g}$ of the crude extract $(70 \% \mathrm{EtOH})$ of E. giganteum or P. granatum was dissolved in $500 \mathrm{ml}$ of deionized water and submitted to LLE for extraction using organic solvents. The solvents were dichloromethane $\left(\mathrm{CH}_{2} \mathrm{Cl}_{2}\right)$, ethyl acetate (AcOEt) and $n$-butanol $(n-\mathrm{BuOH})$ for E. giganteum, and ethyl acetate (AcOEt) and $n$-butanol $(n-\mathrm{BuOH})$ for P. granatum (Sigma-Aldrich ${ }^{\circledR}$ Inc.) St Louis, MO, USA) (Endo et al. 2010). The enriched fractions were concentrated under a vacuum (Heidolph ${ }^{\oplus}$, Schwabach, Germany) and then lyophilized.

\section{Determination of the minimum microbicidal concentration (MMC)}

All the enriched fractions were analyzed using an MMC (minimum microbicidal concentration) assay with $C$. albicans (SC5314) to determine the concentration with antifungal activity. For MMC characterization, 10, 20, 30 and $50 \mathrm{mg}$ of each enriched fraction and 70\% EtOH from E. giganteum or P. granatum were placed in microtubes containing $50 \mu \mathrm{l}$ of DMSO (dimethylsulfoxide Sigma-Aldrich ${ }^{\oplus}$ Inc.) and $950 \mu$ of culture medium (TBS - trypticase soy broth; Sigma-Aldrich ${ }^{\circledR}$ Inc.). The different concentrations of each fraction and extract were distributed in 24-well cell culture plates and homogenized with C. albicans $\left(1 \times 10^{7}\right.$ cells). As controls, $1 \mathrm{ml}$ of inoculum was maintained in TSB (negative control for fungicidal activity) or homogenized with 10,20 or $30 \mathrm{mg}$ of nystatin (positive control for fungicidal activity). The plates were maintained at $37^{\circ} \mathrm{C}$ for $24 \mathrm{~h}$ under agitation $(75 \mathrm{rpm})$. After this period, the different concentrations of each fraction and extract, as well as the controls, were serially diluted, and aliquots of $50 \mu \mathrm{l}$ were seeded in duplicate in Sabouraud Dextrose agar (Difco ${ }^{\oplus}$, Detroit, MI, USA) containing chloramphenicol. The Petri dishes were kept in an incubator at $37^{\circ} \mathrm{C}$ for $24 \mathrm{~h}$. Afterwards, the viable Candida colonies were quantified. A 1:1,000 dilution was considered ideal for counting the colony forming units. For this assay, two independent experiments were performed.

The enriched fractions that presented the best antifungal activity were $\mathrm{CH}_{2} \mathrm{Cl}_{2}$ for $E$. giganteum and AcOEt for $P$. granatum at concentrations of 30 and $50 \mathrm{mg}$. As expected, the positive control (nystatin) had the lowest values at all the evaluated concentrations (Supplemental material Table S1). Considering these results, the cytotoxic effect of 30 and $50 \mathrm{mg}$ of both enriched fractions was evaluated. Briefly, $1 \times 10^{4}$ human gingival fibroblasts (FGH) were cultured in a 96-well cell culture plate previously treated with 30 and $50 \mathrm{mg}$ of enriched fractions containing $10 \mathrm{mg}$ of adhesive ( $\mathrm{AD} / \mathrm{Eg}$ or $\mathrm{AD} / \mathrm{Pg})$, enriched fractions only at these concentrations (Eg or Pg), or adhesive only ( $\mathrm{AD}$ $10 \mathrm{mg}$ ), with culture medium for viability control or with methanol for the cytotoxic control. After $12 \mathrm{~h}$, viability was evaluated by means of the LIVE/DEAD ${ }^{\mathrm{m}}$ Viability/ Cytotoxicity Kit, for mammalian cells (Molecular Probes, Eugene, OR, USA) using a fluorescence assay in accordance with the manufacturer's instructions. To analyze viable cells, the means of relative fluorescence were obtained using a spectrophotometer at $485 / 530 \mathrm{~nm}$ for calcein. A qualitative assay was also performed by image analysis of the cells labeled with calcein and/or with an ethidium homodimer (nonviable) and a Leica DM IRBE inverted microscope (LEICA Microsystems, Wetzlar, Germany). Considering that the highest concentration $(50 \mathrm{mg}$ ) was more cytotoxic, a concentration of $30 \mathrm{mg}$ for both the enriched fractions was chosen for the following assay. Three independent experiments were performed in triplicate (Supplemental material Figure S1).

\section{Fabrication of specimens}

The specimens were fabricated as described by Silva et al. (2016) with some modifications. A total of 800 heatcured acrylic resin specimens (Lucitone 550; Dentsply International Inc., Chicago, MI, USA) were made $(10 \mathrm{~mm} \times 10 \mathrm{~mm} \times 5 \mathrm{~mm})$ according to the manufacturer's instructions. Both sides of all the specimens were ground in a horizontal polisher (ER 27000; Erios, São Paulo, Brazil) and were randomly selected to simulate the inner portion of the denture base with a mean surface roughness (Ra) of $3 \mu \mathrm{m}$ (Surftest SJ-301; Mitutoyo Corporation, Kanagawa, Japan). After polishing, the specimens were immersed in distilled water at $37^{\circ} \mathrm{C}$ for $48 \mathrm{~h}$ to allow the release of the residual monomers (Neppelenbroek et al. 2005) and sent for sterilization using ethylene oxide (Acecil $^{\bullet}$ - Central Sterilization of Commerce and Industry Ltda, Campinas, Brazil).

\section{Surface treatment of specimens}

Aliquots of $30 \mathrm{mg}$ of enriched fractions $\left(\mathrm{CH}_{2} \mathrm{Cl}_{2}\right.$ and AcOEt) were diluted in $50 \mu \mathrm{l}$ of DMSO and then mixed with $10 \mathrm{mg} \mathrm{ml}^{-1}$ of denture adhesive powder (COREGA ${ }^{\circ}$ powder, GlaxoSmithKline Brazil Ltda, Rio de Janeiro, Brazil) according to previous reports (de Gomes et al. 2011; Garaicoa et al. 2016; Bates et al. 2017). This mixture was suspended and mechanically homogenized in $1 \mathrm{ml}$ of PBS (phosphate-buffered saline, Sigma-Aldrich ${ }^{\oplus}$ Inc.). The entire volume of the suspension was brushed onto the acrylic resin specimen surfaces which were then placed in a 24-well cell culture plate for $50 \mathrm{~min}$, to allow for the complete adhesion of all the components on the surfaces. Then, the specimens were dried at room temperature for $24 \mathrm{~h}$. 
As controls, some specimens were untreated and immersed in PBS, allowing fungal growth, while others were treated only with $10 \mathrm{mg} \mathrm{ml}^{-1}$ of denture adhesive powder $\left(\mathrm{COREGA}^{\circ}\right)$ to evaluate the possible antimicrobial action of the vehicle or with an adhesive/nystatin combination $\left(10 \mathrm{mg} \mathrm{ml}^{-1}\right.$ of adhesive and $32 \mathrm{mg} \mathrm{ml}^{-1}$ of nystatin - Pharmacia Specifica Ltda, Bauru, Brazil) (Bueno et al. 2015) to authenticate antimicrobial action. Thus, the samples were randomly divided into five groups $(n=2$ per group in each experiment): $\mathrm{AD}$ - surface treated only with $\mathrm{COREGA}^{\oplus}$ powder $\left(10 \mathrm{mg} \mathrm{ml}^{-1}\right), \mathrm{AD} / \mathrm{Eg}$ - with the combination COREGA ${ }^{\oplus}$ and $\mathrm{CH}_{2} \mathrm{Cl}_{2}\left(10\right.$ and $\left.30 \mathrm{mg} \mathrm{ml}^{-1}\right), \mathrm{AD} /$ $\mathrm{Pg}$ - with the combination COREGA ${ }^{\circ}$ and AcOEt (10 and $\left.30 \mathrm{mg} \mathrm{ml}^{-1}\right), \mathrm{AD} / \mathrm{Nt}$ - with the combination COREGA ${ }^{\oplus}$ and nystatin (10 and $32 \mathrm{mg} \mathrm{ml}^{-1}$ ) and PBS - specimens kept only in PBS without treatment.

\section{Microorganism and biofilm growth}

C. albicans (SC5314) was grown in YEPD broth (Difco ${ }^{\circ}$, Sparks, MD, USA), and cells were inoculated into Sabouraud dextrose broth (Difco ${ }^{\circledR}$ ) to obtain only the yeastform. The inoculum was standardized at a concentration of $10^{7}$ cells $\mathrm{ml}^{-1}$. C. albicans was then grown according to the method proposed by Chandra et al. (2001) with some modifications. After treatment (AD, $\mathrm{AD} / \mathrm{Eg}, \mathrm{AD} /$ $\mathrm{Pg}, \mathrm{AD} / \mathrm{Nt}$ ) or not (PBS), the specimens were placed in a 24-well cell culture plate containing $1 \mathrm{ml}$ of inoculum. To allow fungal adhesion, the plates were incubated at $37^{\circ} \mathrm{C}$ for $90 \mathrm{~min}$, under agitation $(75 \mathrm{rpm})$. Subsequently, the non-adherent fungal cells were removed by washing the specimens with PBS, and then transferring them to another 24-well cell culture plate. Afterwards, for biofilm growth, the specimens were immersed in $1 \mathrm{ml}$ of RPMI1640 culture medium (Roswell Park Memorial Institute Sigma-Aldrich ${ }^{\circledast} \mathrm{Inc}$.) and incubated at $37^{\circ} \mathrm{C}$ under agitation (75 rpm) (Kumamoto 2002; Bizerra et al. 2008).

After incubation time intervals of 3,6 or $12 \mathrm{~h}$, the specimens were carefully washed three times with $1 \mathrm{ml}$ of PBS. At this point, the C. albicans biofilm formed on the acrylic resin surface of the specimens was evaluated by the counting colony forming units per milliliter $\left(\mathrm{CFU} \mathrm{m} \mathrm{m}^{-1}\right)$, the metabolic activity according to the percentage reduction of XTT to formazan (XTT assay), ultrastructural analysis by scanning electron microscopy (SEM) and biofilm mass quantification by confocal laser scanning microscopy (CLSM).

\section{Biofilm quantification by counting colony forming units (CFU ml-1)}

Three independent experiments were performed for each incubation time interval. After biofilm growth, the fungal cells, which were adhered to the specimens previously accommodated in the 24-well cell culture plate, were gently detached using a cell scraper (Costar ${ }^{\circledR} 3010$, Corning Incorporated, Corning, NY, USA) (Tobudic et al. 2010). Afterwards, the suspension containing the fungal cells was recovered and serially diluted. Aliquots $(50 \mu \mathrm{l})$ of each dilution, in duplicate, were seeded in Sabouraud dextrose agar $\left(\mathrm{Difco}^{\circ}\right)$ containing chloramphenicol and incubated at $37^{\circ} \mathrm{C}$ for $24 \mathrm{~h}$ (Estivill et al. 2011). Then, viable colonies of Candida were visually quantified by counting the colony forming units $\left(\mathrm{CFU} \mathrm{ml}{ }^{-1}\right)$.

\section{Biofilm quantification by the XTT reduction assay}

The XTT (2,3 bis (2-methoxy-4-nitro-5-sulfophenyl)-5[(amino phenyl) carbonyl]-2H-tetrazolium hydroxide) reduction assay was performed as previously reported (Pierce et al.2008), with some modifications. Briefly, after biofilm growth for 3, 6 and $12 \mathrm{~h}$ in a 24-well cell culture plate, $2 \mathrm{ml}$ of XTT solution at $0.5 \mathrm{mg} \mathrm{ml}^{-1}$ menadione, $0.1 \mathrm{mM}$ (Sigma-Aldrich ${ }^{\oplus}$ Inc.) were added to each well containing the previously treated or untreated specimens. The plates were covered with aluminum foil and incubated at $37^{\circ} \mathrm{C}$ for $3 \mathrm{~h}$. Then, a volume of $1.6 \mathrm{ml}$ from each well was centrifuged at $10^{\circ} \mathrm{C}$ for $2 \mathrm{~min}$ at $10,000 \mathrm{rpm}$ to decant the fungal cells present in the supernatant (Chandra et al. 2001; Kuhn et al. 2003). Aliquots of $200 \mu$ l were plated in triplicate in a 96-well plate $\left(\mathrm{TPP}^{\circledast}\right.$ - Techno Plastic Products, Trasadingen, Switzerland) and analyzed by absorbance at $550 \mathrm{~nm}$ using a spectrophotometer (Biotek Synergy MX based Monochromator ${ }^{\oplus}$, Winoosky, VT, USA) to evaluate the metabolic activity of the viable $C$. albicans cells in the biofilm. Three independent experiments were performed for each time interval.

\section{Ultrastructural characteristics of C. albicans biofilm established by SEM}

To authenticate the antimicrobial activity of the enriched fractions and nystatin, after biofilm growth for 3, 6, or $12 \mathrm{~h}$ on the surface of the acrylic resin previously treated (AD, $\mathrm{AD} / \mathrm{Eg}, \mathrm{AD} / \mathrm{Pg}, \mathrm{AD} / \mathrm{Nt}$ ) or not (PBS), the specimens were transferred to another 24-well cell culture plate and gently washed three times with $1 \mathrm{ml}$ of sodium cacodylate buffer $(0.05 \mathrm{M}, \mathrm{pH} 7.4)$. After washing, the specimens were fixed in glutaraldehyde (2.5\%) for $30 \mathrm{~min}$ ( $\mathrm{pH} 7.4$ ), and washed again with $1 \mathrm{ml}$ of sodium cacodylate buffer and postfixed with $1 \%$ aqueous osmium tetra-oxide $\left(\mathrm{w} \mathrm{v}^{-1}\right)$ for $20 \mathrm{~min}$ at room temperature. The osmium tetra-oxide was then displaced with sodium cacodylate buffer. Afterwards, the specimens were treated with increasing percentages $(30-100 \%)$ of ethanol (3 min each) to dehydrate the biofilms. The specimens were dried with $1 \mathrm{ml}$ of hexamethyldisilazane (HDMS - Sigma-Aldrich ${ }^{\circledast}$ Inc.) for $10 \mathrm{~min}$. 
Finally, each specimen was mounted on an aluminum stub and sputter-coated with gold for SEM examination of the $C$. albicans biofilms. This experiment was performed in duplicate in each group $(n=10)$ (Abdul Razak et al. 2017).

\section{C. albicans biofilm mass analysis by CLMS}

After biofilm growth for 3,6 , or $12 \mathrm{~h}$ on the surface of the acrylic resin previously treated $(\mathrm{AD}, \mathrm{AD} / \mathrm{Eg}, \mathrm{AD} /$ $\mathrm{Pg}, \mathrm{AD} / \mathrm{Nt}$ ) or not (PBS), the specimens were transferred to another 24-well cell culture plate and delicately washed three times in $1 \mathrm{ml}$ of PBS. The specimens were then stained with $200 \mu \mathrm{l}$ of the LIVE/DEAD BacLight Bacterial Viability Kit solution (Molecular Probes) and incubated at room temperature, in the dark for $15 \mathrm{~min}$. Subsequently, the specimens were examined in a CLMS (Leica Microsystems GmbH, Mannheim, Germany) from which digital images were obtained. The cells were labeled in green using SYTO 9 or red using propidium iodide for viable and dead cells, respectively. With the use of the BioImage Software program, the biofilm mass was quantified, including both the viable and nonviable cells, and expressed as $\mu \mathrm{m}^{3}$. The greater the decrease in the biofilm mass of the specimens, the higher the anti-biofilm activity. This experiment was performed in duplicate per group ( $n$ =10) (Alavarce et al. 2015).

\section{Statistical analysis}

The results were analyzed by mean \pm SD and expressed according to the normality pattern (KolmogorovSmirnov). For the CFU ml ${ }^{-1}$, the Kruskal-Wallis test for comparison was applied between the times and groups; additionally, the Mann-Whitney test was used to determine differences between the experimental groups and controls. For the XTT reduction assay, the results were subjected to two-way analysis of variance (ANOVA), followed by post hoc Tukey HSD (honest significant difference). In parallel, the Dunnett test was performed. The difference was considered statistically significant when $p \leq 0.05$.

\section{Results and discussion}

\section{Enriched fractions of $\mathrm{E}$. giganteum or P. granatum amplified the adhesive ability to interfere with $\mathrm{C}$. albicans biofilm growth}

Denture adhesives, such as COREGA ${ }^{\oplus}$, are widely used among wearers of maxillary completely removable dentures because they improve the quality of mastication and the retention of dentures on the supporting mucosa (Folse 2004; Sato et al. 2008; Bartlett et al. 2013). Thus, they are materials for temporary use, which allow a better distribution of occlusal forces, thereby minimizing tissue trauma and the risk of developing DS (Tarbet et al. 1980; Perez et al. 1985). The composition of COREGA ${ }^{\oplus}$ contains no potential antifungal component. However, the adhesive has polyethylene glycol (PEG), which significantly reduces the interaction of microbial cells with the biomaterial surface by forming a physical barrier that hinders fungal adhesion and consequently prevents microbial infections (Park et al. 1998; Xu and Siedlecki 2012, 2014, 2017).

In the present study, this adhesive interfered with adherence and growth of $C$. albicans biofilm on the surface of the resin specimens ( $\mathrm{AD}$ group). The biofilm of these specimens showed lower CFU ml ${ }^{-1}$ values and decreased metabolic activity in comparison with those obtained in the untreated group (PBS) at all evaluation time intervals ( 3,6 and $12 \mathrm{~h}$ ) (Figures $1 \mathrm{~A}, \mathrm{~B}, 2 \mathrm{~A}, \mathrm{~B}, 3 \mathrm{~A}$ and $\mathrm{B}$ ). In agreement with these results, SEM analysis revealed that fungal colonization had a less dense layer on the surfaces treated with adhesive $(\mathrm{AD})$ compared with the untreated surfaces (PBS) (Figures 1C, 2C and 3C), which could be confirmed by their lower biomass values as quantified by CLMS after all periods (mean values of 14.195; 23.842 and $14.396 \mu^{3}$ for $\mathrm{AD} ; 29.950$; 99.984 and $140.304 \mu \mathrm{m}^{3}$ for PBS, respectively 3, 6 and $12 \mathrm{~h}$ ) (Figures 1D, 2D and 3D).

Therefore, the denture adhesive by itself was a factor interfering with the growth of the yeast cells adhered to the acrylic resin surface. In view of this ability to control the biofilm formation process, the PEG present in COREGA $^{\oplus}$ was possibly one of the factors responsible for the reduction in C. albicans colonization, hampering the development of biofilms on the resin surface treated only with this material.

The present results also revealed that these anti-biofilm effects were even greater when the resin was treated with E. giganteum or P. granatum incorporated into the adhesive. Statistically significant differences in $\mathrm{CFU} \mathrm{ml}{ }^{-1}$ values were found when $\mathrm{AD} / \mathrm{Eg}$ and $\mathrm{AD} / \mathrm{Pg}$ were compared with the $\mathrm{AD}$ group in all periods $(\mathrm{AD} / \mathrm{Eg} v s \mathrm{AD}: p<0.001$ for 3, 6 and $12 \mathrm{~h}$; and $\mathrm{AD} / \mathrm{Pg} v s \mathrm{AD}: p<0.01$ for 3 and $6 \mathrm{~h}$, and $p=0.047$ for $12 \mathrm{~h}$ ). The $\mathrm{CFU} \mathrm{ml} \mathrm{m}^{-1}$ values obtained after treatment with herbal medicines were similar to each other, irrespective of the time interval (Figures 1A, 2A and $3 \mathrm{~A})$. Accordingly, the treatment with E. giganteum and $P$. granatum was associated with a higher percentage reduction in the metabolic activity of the $C$. albicans biofilm attached to resin, in comparison with the $\mathrm{AD}$ group $(p<$ 0.001 for all periods). When comparing herbal extracts, E. giganteum treatment resulted in a higher percentage metabolic reduction of Candida in the biofilm at all the time intervals (AD/Eg vs $\mathrm{AD} / \mathrm{Pg}: p=0.000021 ; 0.000022$; 0.000049 , respectively at 3,6 and $12 \mathrm{~h}$ ) (Figures $1 \mathrm{~B}, 2 \mathrm{~B}$ and $3 \mathrm{~B}$ ). In the initial period, $3 \mathrm{~h}$ post-biofilm growth, 
the percentage reduction in the metabolic activity of $C$. albicans in the $\mathrm{AD} / \mathrm{Eg}$ group was similar to that of the treatment with the adhesive/nystatin combination (AD/ $\mathrm{Nt}$ ) (Figure 1B).

As expected, the $\mathrm{AD} / \mathrm{Nt}$ group showed the lowest $C$. albicans $\mathrm{CFU} \mathrm{ml}{ }^{-1}$ values, irrespective of the biofilm formation time interval. Moreover, nystatin significantly reduced the metabolism of the $C$. albicans that adhered to the acrylic resin, with mean values above $95 \%$ (Figures $1 \mathrm{~A}, \mathrm{~B}, 2 \mathrm{~A}, \mathrm{~B}, 3 \mathrm{~A}$ and $\mathrm{B}$ ).

Amplification of adhesive antifungal activity by the addition of E. giganteum and P. granatum enriched fractions was also confirmed by SEM analysis. When any of the plant extracts were incorporated into $\mathrm{COREGA}^{\bullet}(\mathrm{AD} /$ $\mathrm{Eg}$ or $\mathrm{AD} / \mathrm{Pg}$ ), the reduction in the biofilm layer on the resin surface was notable compared with the $\mathrm{AD}$ group in all periods. The ultrastructural images showed a biofilm that consisted of agglomerations of yeasts and hyphae-like forms in the $\mathrm{AD}$ group. In contrast, there was no dense and continuous fungal layer in the herbal groups $(\mathrm{AD} / \mathrm{Eg}$ or $\mathrm{AD} / \mathrm{Pg})$, and the nystatin group $(\mathrm{AD} / \mathrm{Nt})$ that presented only a few yeast fungal cells, which increased slightly over time, without the presence of hyphae-like forms. In the control group, a layer of $C$. albicans cells adhered to the entire surface of untreated specimens (PBS), which became denser in the later periods. This layer was composed of yeasts and hyphae-like forms that were grouped in the extracellular polymeric substances (EPSs) (Figures 1C, 2C and 3C). C. albicans has the inherent potential to form quantitatively significant biofilms (Kuhn, Chandra, et al. 2002; Kuhn, George, et al. 2002). It was very interesting to note this important effect of both herbal extracts $(E$. giganteum and $P$. granatum) on the ability of $C$. albicans to switch from yeast cells to hyphae-like forms. The polymorphism of $C$. albicans is one of its main virulence factors during infection. By means of this morphologic switching, virulent strains can disrupt the epithelial integrity and invade the host tissue. This process is attributed to C. albicans clonal types and is associated with the pathogenesis of DS (Altarawneh et al. 2013).

Similar to the SEM analysis, quantification by CLSM showed that the biofilms on specimens treated with herbal extracts or nystatin $(\mathrm{AD} / \mathrm{Eg}, \mathrm{AD} / \mathrm{Pg}$ and $\mathrm{AD} / \mathrm{Nt})$ exhibited lower mean biomass values $\left(\mu \mathrm{m}^{3}\right)$ and concomitantly a lower mean percentage of viable fungal cells (green) compared with $\mathrm{AD}$-treated resin, in the 3 and $6 \mathrm{~h}$ time intervals $\left(3,036.5\right.$ to $6,334.6 \mu \mathrm{m}^{3} / 15.3$ to $44.2 \%$ for groups treated with herbal extracts or nystatin and 14.195 $\mu^{3} / 70.5 \%$ for $\mathrm{AD}$ group after $3 \mathrm{~h}$; and 2,915.3 to 6,519.5 $\mu^{3} / 21.1$ to $82.3 \%$ for groups treated with herbal extracts or nystatin and $23.842 \mu \mathrm{m}^{3} / 94.7 \%$ for AD group after $6 \mathrm{~h}$ ) (Figures 1D, 2D and 3D). Among the medicinal plants, only treatment with $\mathrm{CH}_{2} \mathrm{Cl}_{2}$ of E. giganteum resulted in control of the biofilm mass in comparison with the $\mathrm{AD}$ group even after $12 \mathrm{~h}$ of $C$. albicans biofilm development (3,602.7 vs $14,396.4 \mu \mathrm{m}^{3}$, respectively).

The benefits of the $70 \% \mathrm{EtOH}$ extract of E. giganteum against $C$. albicans biofilms have previously been reported and associated with the presence of flavonoids, since these compounds are able to inactivate the proteins responsible for the adhesion of fungal cells to the substratum and biofilm growth (Alavarce et al. 2015). In addition, flavonoids inactivate some carrier proteins, alter the membrane permeability of the fungal cells (Cowan 1999; CalderonMontano et al. 2011; Kumar and Pandey 2013) and cause oxidative stress in the biofilm matrix of $C$. albicans, thus hindering their growth (Peralta et al. 2015). In the same context, it was recently found that ellagitannin derivatives, which are highlighted as major components identified in the crude hydroalcoholic extract from P. granatum peels $(70 \% \mathrm{EtOH})$, have anti-biofilm action, causing serious damage to the cellular structure of $C$. albicans yeast (Fischer et al. 2011; Anibal et al. 2013; Bakkiyaraj et al. 2013).

Finally, these results authenticate the antifungal activity of E. giganteum and P. granatum when associated with COREGA ${ }^{\oplus}$, but the mechanism responsible for the anti-biofilm action of the herb extracts on the surface of the previously treated acrylic resin was not clearly elucidated, since these herbs can act on different fungal structures, either cellular or molecular, during biofilm development and fungal adhesion (Braga et al. 2008; Liu 2013). However, the present study showed the important influence of E. giganteum and P. granatum extracts on the reduction in colonization, metabolic activity, density and morphology of C. albicans biofilms adhered to an acrylic resin surface treated with a combination of adhesive/herb extracts.

Therefore, it seems reasonable to conclude that both herbal extracts (E. giganteum and P. granatum) improved the antifungal activity of the denture adhesive used in this study. This means that the incorporation of herbal medicine extracts into denture adhesives, such as COREGA ${ }^{\circ}$, amplified their ability to interfere with the development of the Candida biofilm adhered to the surface of the polymerized acrylic resin. This may be potentially innovative for clinical practice, deserving additional laboratory and subsequent clinical studies to rule out the possible harmful action on human tissues and denture adhesives.

\section{Clinical applicability and advantages of the association of $\mathrm{E}$. giganteum or $\mathrm{P}$. granatum extracts with COREGA ${ }^{\circledR}$ over time}

Based on this in vitro experimental model, it was possible to detect increased susceptibility of fungal cells to 
resin treated with adhesive/herbal extract combinations. Although the tested combinations did not show similarity to nystatin at all concentrations in this study, the adhesive associated with E. giganteum or P. granatum was effective against the development of $C$. albicans biofilms on the acrylic resin surfaces. This combination should be studied in more depth, since it may provide clinical benefit to the prevention and therapy of DS.

Although the use of nystatin causes some side effects, such as unpleasant tastes, diarrhea, nausea, vomiting, epigastric pain and the recurrence of inflammation, due to C. albicans resistance (Mansourian et al. 2014), it is important to emphasize the role of nystatin as a conventional antifungal agent for the treatment of fungal infections, including DS. This work does not propose replacing nystatin, but rather to suggest that the addition of herbal medicine extracts with antimicrobial properties, such as E. giganteum and P. granatum or their molecules that are responsible for this action, could maximize the benefits of using denture adhesive in the case of completely removable denture wearers. Moreover, this combination will allow antimicrobial agents to remain close to both the internal surface of the base of the contaminated dental prosthesis and the oral mucosa surface, enabling preventive and therapeutic actions.

Furthermore, to achieve successful treatment of DS, nystatin is often recommended three times a day for 15 days, further exacerbating its deleterious effects (Hawser and Islam 1999). Finally, it is worth noting that many geriatric patients, dependent on professional caregivers or hospital, present considerable difficulties and limitations in medicating at the recommended time intervals, including the use of antifungal agents. For these reasons, new therapeutic and/or preventive proposals for DS should be scientifically explored, including associations of temporary adhesives with herbal extracts that have not been associated with undesirable effects on the oral mucosa/human cells (Cerda et al. 2003; Vidal et al. 2003; Alavarce et al. 2015; Carraz et al. 2015; Jabeur et al. 2017).

The antifungal activity observed in this study, mainly after incorporating herbal medicine extracts into the adhesive, remained for over $12 \mathrm{~h}$. This can also be explained by the presence of PEG, a nonconventional antifungal component capable of reducing the interaction of microbial cells with the biomaterial surface. PEG has been successfully incorporated as a carrier into conventional antifungal agents, such as amphotericin B and nystatin, as well as essential oils, such as clove, cinnamon and garlic. The combination of PEG with compounds that have antimicrobial activity has been considered a promising alternative to aid in the treatment of infections caused by C. albicans, S. aureus or Campylobacter jejuni (Llabot et al. 2007a, 2007b; Ahmed et al. 2016; Halperin et al. 2016).
The PEG present in COREGA ${ }^{\circ}$ possibly served as a good carrier for extracts of both herbs (E. giganteum and $P$. granatum) incorporated into the adhesive, allowing interference in the development of the C. albicans biofilm and throughout the experimental time of up to $12 \mathrm{~h}$. As these are adhesives, longer antifungal efficacy times may not be necessary, since adhesives in the form of creams or powders reach their adhesion potential 2-4 $\mathrm{h}$ after the first application (Grasso et al. 1994). After $6 \mathrm{~h}$ of use, they lose $\sim 30-50 \%$ of their effectiveness as they are removed by saliva (Chew 1990; Ghani and Picton 1994; Kulak et al. 2005; Koronis et al. 2012). For COREGA ${ }^{\circledR}$, the maximum time of use, according to the manufacturer, must not exceed $12 \mathrm{~h}$, after which it needs to be reapplied to maintain its function. Moreover, denture hygiene involves the mechanical process of cleaning the internal and external surfaces, ideally after meals. Consequently, the remaining adhesive will be removed anyway and will require a fresh application.

Finally, considering the main functions of the adhesive, it is crucial to perform mechanical tests to verify whether the association of COREGA ${ }^{\star}$ with the herbal medicine extracts studied in this research could alter these functions. The antimicrobial potential of these combinations highlights that the incorporation of $E$. giganteum or P. granatum extracts into COREGA ${ }^{\star}$ could aid the therapeutic and/or preventive approaches to DS, by acting on the main etiological factor, the fungus $C$. albicans.

\section{Conclusion}

When E. giganteum and P. granatum extracts were combined with COREGA ${ }^{\oplus}$, they interfered with the development of C. albicans biofilms on the surface of the polymerized acrylic resin, especially minimizing their colonization and reducing their metabolism. Therefore, this association played a synergistic and innovative role as a temporary material and may aid the treatment and/ or prevention of DS.

\section{Acknowledgments}

The authors thank Dr Gisele da Silva Dalben, Margery Galbraith and Taylor \& Francis English Language Editing service for their English Language editing services, Prof. Dr José Roberto Pereira Lauris for statistical analyses of this work, Marcia Sirlene Zardin Graeff for CLSM analysis and Tatiani Ayako Goto Donato for the SEM analysis.

\section{Disclosure statement}

The authors declare that they have no conflict of interest. 


\section{Funding}

This work was supported by the São Paulo Research Foundation - FAPESP [grant numbers 2012/12458-9, 2014/07012-7, 2015/03965-2].

\section{ORCID}

Rafaela Alves da Silva (D) http://orcid.org/0000-0002-95842045

Vinicius Carvalho Porto (D) http://orcid.org/0000-0002-66099934

Vanessa Soares Lara (iD http://orcid.org/0000-0003-1986-0003

\section{References}

Abdul Razak F, Baharuddin BA, Akbar EFM, Norizan AH, Ibrahim NF, Musa MY. 2017. Alternative sweeteners influence the biomass of oral biofilm. Arch Oral Biol. 80:180-184. doi: 10.1016/j.archoralbio.2017.04.014.

Ahmed J, Hiremath N, Jacob H. 2016. Antimicrobial, rheological, and thermal properties of plasticized polylactide films incorporated with essential oils to inhibit Staphylococcus aureus and Campylobacter jejuni. J Food Sci. 81:E419-429. doi: 10.1111/jfds.2016.81.issue-2.

Alavarce RA, Saldanha LL, Almeida NL, Porto VC, Dokkedal AL, Lara VS. 2015. The beneficial effect of Equisetum giganteum L. against Candidabiofilm formation: new approaches to denture stomatitis. Evid Based Complement Alternat Med. 2015:939625.

Altarawneh S, Bencharit S, Mendoza L, Curran A, Barrow D, Barros S, Preisser J, Loewy ZG, Gendreau L, Offenbacher S. 2013. Clinical and histological findings of denture stomatitis as related to intraoral colonization patterns of Candida albicans, salivary flow, and dry mouth. J Prosthodont. 22:13-22. doi: 10.1111/jopr.2013.22.issue-1.

Anibal PC, Peixoto IT, Foglio MA, Hofling JF. 2013. Antifungal activity of the ethanolic extracts of Punica granatum L. and evaluation of the morphological and structural modifications of its compounds upon the cells of Candida spp. Braz J Microbiol. 44:839-848. doi: 10.1590/S151783822013005000060.

Arendorf TM, Walker DM. 1987. Denture stomatitis: a review. J Oral Rehabil. 14:217-227. doi: 10.1111/jor.1987.14.issue-3.

Aslanimehr M, Rezvani S, Mahmoudi A, Moosavi N. 2017. Comparison of Candida albicans adherence to conventional acrylic denture base materials and injection molding acrylic materials. J Dent (Shiraz). 18:61-64.

Bakkiyaraj D, Nandhini JR, Malathy B, Pandian SK. 2013. The anti-biofilm potential of pomegranate (Punica granatum L.) extract against human bacterial and fungal pathogens. Biofouling. 29:929-937. doi: 10.1080/08927014.2013.820825.

Barbeau J, Seguin J, Goulet JP, de Koninck L, Avon SL, Lalonde B, Rompre P, Deslauriers N. 2003. Reassessing the presence of Candida albicans in denture-related stomatitis. Oral Surg Oral Med Oral Pathol Oral Radiol Endod. 95:51-59. doi: 10.1067/moe.2003.44.

Bartlett DW, Maggio B, Targett D, Fenlon MR, Thomas J. 2013. A preliminary investigation into the use of denture adhesives combined with dietary advice to improve diets in complete denture wearers. J Dentistry. 41:143-147. doi: 10.1016/j.jdent.2012.10.012.

Bates AM, Garaicoa JL, Fischer CL, Brogden KA. 2017. Diminished antimicrobial peptide and antifungal antibiotic activities against Candida albicans in denture adhesive. Antibiotics. [accessed 2017 Nov 30]:[5 p.]. http://www. mdpi.com/2079-6382/6/1/6.

Bizerra FC, Nakamura CV, de Poersch C, Estivalet Svidzinski TI, Borsato Quesada RM, Goldenberg S, Krieger MA, YamadaOgatta SF. 2008. Characteristics of biofilm formation by Candida tropicalis and antifungal resistance. FEMS Yeast Res. 8:442-450. doi: 10.1111/j.1567-1364.2007.00347.x.

Bollen CM, Lambrechts P, Quirynen M. 1997. Comparison of surface roughness of oral hard materials to the threshold surface roughness for bacterial plaque retention: a review of the literature. Dent Mater. 13:258-269. doi: 10.1016/S01095641(97)80038-3.

Braga PC, Culici M, Alfieri M, Dal Sasso M. 2008. Thymol inhibits Candida albicans biofilm formation and mature biofilm. Int J Antimicrob Agents. 31:472-477. doi: 10.1016/j. ijantimicag.2007.12.013.

Budtz-Jorgensen E. 1978. Clinical aspects of Candida infection in denture wearers. J Am Dent Assoc. 96:474-479. doi: 10.14219/jada.archive.1978.0088.

Budtz-Jorgensen E. 1990. Etiology, pathogenesis, therapy, and prophylaxis of oral yeast infections. Acta Odontol Scand. 48:61-69. doi: 10.3109/00016359009012735.

Budtz-Jorgensen E, Bertram U. 1970. Denture stomatitis. I. The etiology in relation to trauma and infection. Acta Odontol Scand. 28:71-92. doi: 10.3109/00016357009033133.

Bueno MG, Urban VM, Barberio GS, da Silva WJ, Porto VC, Pinto L, Neppelenbroek KH. 2015. Effect of antimicrobial agents incorporated into resilient denture relines on the Candida albicans biofilm. Oral Dis. 21:57-65. doi: 10.1016/ S0031-9422(96)00543-2.

Calderon-Montano JM, Burgos-Moron E, Perez-Guerrero C, Lopez-Lazaro M. 2011. A review on the dietary flavonoid kaempferol. Mini Rev Med Chem. 11:298-344. doi: 10.2174/138955711795305335.

Carraz M, Lavergne C, Jullian V, Wright M, Gairin JE, Gonzales de la Cruz M, Bourdy G. 2015. Antiproliferative activity and phenotypic modification induced by selected Peruvian medicinal plants on human hepatocellular carcinoma Hep3B cells. J Ethnopharmacol. 166:185-199. doi: 10.1016/j. jep.2015.02.028.

Casaroto AR, Lara VS. 2010. Phytomedicines for Candidaassociated denture stomatitis. Fitoterapia. 81:323-328. doi: 10.1016/j.fitote.2009.12.003.

Cerda B, Ceron JJ, Tomas-Barberan FA, Espin JC. 2003. Repeated oral administration of high doses of the pomegranate ellagitannin punicalagin to rats for 37 days is not toxic. J Agric Food Chem. 51:3493-3501. doi: 10.1021/ jf020842c.

Chandra J, Kuhn DM, Mukherjee PK, Hoyer LL, McCormick T, Ghannoum MA. 2001. Biofilm formation by the fungal pathogen Candida albicans: development, architecture, and drug resistance. J Bacteriol. 183:5385-5394. doi: 10.1128/ JB.183.18.5385-5394.2001.

Chau VB, Saunders TR, Pimsler M, Elfring DR. 1995. In-depth disinfection of acrylic resins. J Prosthet Dent. 74:309-313. doi: 10.1016/S0022-3913(05)80140-4. 
Chew CL. 1990. Retention of denture adhesives - an in vitro study. J Oral Rehabil. 17:425-434. doi: 10.1111/jor.1990.17. issue-5.

Cowan MM. 1999. Plant products as antimicrobial agents. Clin Microbiol Rev. 12:564-582.

de Gomes PS, Figueiral MH, Fernandes MH, Scully C. 2011. Cytotoxicity of denture adhesives. Clin Oral Invest. 15:885893.

Endo EH, Cortez DA, Ueda-Nakamura T, Nakamura CV, Dias Filho BP. 2010. Potent antifungal activity of extracts and pure compound isolated from pomegranate peels and synergism with fluconazole against Candida albicans. Res Microbiol. 161:534-540. doi: 10.1016/j.resmic.2010.05.002.

Endo EH, Ueda-Nakamura T, Nakamura CV, Filho BP. 2012. Activity of spray-dried microparticles containing pomegranate peel extract against Candida albicans. Molecules. 17:10094-10107. doi: 10.3390/ molecules170910094.

Estivill D, Arias A, Torres-Lana A, Carrillo-Munoz AJ, Arevalo MP. 2011. Biofilm formation by five species of Candida on three clinical materials. J Microbiol Methods. 86:238-242. doi: 10.1016/j.mimet.2011.05.019.

Fischer UA, Carle R, Kammerer DR. 2011. Identification and quantification of phenolic compounds from pomegranate (Punica granatum L.) peel, mesocarp, aril and differently produced juices by HPLC-DAD-ESI/MS(n). Food Chem. 127:807-821. doi: 10.1016/j.foodchem.2010.12.156.

Folse GJ. 2004. Denture adhesives: when, why, and how. Dent Today. 23:70-71.

Garaicoa JL, Fischer CL, Bates AM, Holloway J, Avila-Ortiz G, Guthmiller JM, Johnson GK, Stanford C, Brogden KA. 2016. Promise of combining antifungal agents in denture adhesives to fight Candida species infections. J Prosthodont. [accessed 2017 Nov 30]:[8 p.]. http://onlinelibrary.wiley. com/doi/10.1111/jopr.12565/epdf.

Ghani F, Picton DC. 1994. Some clinical investigations on retention forces of maxillary complete dentures with the use of denture fixatives. J Oral Rehabil. 21:631-640.

Grasso JE. 2004. Denture adhesives. Dent Clin North Am. Jul;48:721-733, vii. doi: 10.1016/j.cden.2004.04.002.

Grasso JE, Rendell J, Gay T. 1994. Effect of denture adhesive on the retention and stability of maxillary dentures. J Prosthet Dent. 72:399-405. doi: 10.1016/S0031-9422(96)00543-2.

Halperin A, Shadkchan Y, Pisarevsky E, Szpilman AM, Sandovsky H, Osherov N, Benhar I. 2016. Novel watersoluble amphotericin B-PEG conjugates with low toxicity and potent in vivo efficacy. J Med Chem. 59:1197-1206. doi: 10.1021/acs.jmedchem.5b01862.

Hawser S, Islam K. 1999. Comparisons of the effects of fungicidal and fungistatic antifungal agents on the morphogenetic transformation of Candida albicans. J Antimicrob Chemother. 43:411-413. doi: 10.1093/jac/43.3.411.

Heinemann V, Bosse D, Jehn U, Debus A, Wachholz K, Forst H, Wilmanns W. 1997. Enhanced pulmonary accumulation of liposomal amphotericin B (AmBisome) in acute liver transplant failure. J Antimicrob Chemother. 40:295-297. doi: $10.1093 / \mathrm{jac} / 40.2 .295$.

Huang F, Wu W. 2005. Antidiabetic effect of a new peptide from Squalus mitsukurii liver (S-8300) in alloxan-diabetes. Clin Exp Pharmacol Physiol. 32:521-525. doi: 10.1111/ cep.2005.32.issue-7.
Jabeur I, Martins N, Barros L, Calhelha RC, Vaz J, Achour L, Santos-Buelga C, Ferreira IC. 2017. Contribution of the phenolic composition to the antioxidant, anti-inflammatory and antitumor potential of Equisetum giganteum L. and Tilia platyphyllos Scop. Food Funct. 8:975-984. doi: 10.1039/ C6FO01778A.

Koo H, Rosalen PL, Cury JA, Ambrosano GMB, Murata RM, Yatsuda R, Ikegaki M, Alencar SM, Park YK. 2000. Effect of a new variety of Apis mellifera propolis on mutans streptococci. Curr Microbiol. 41:192-196. doi: 10.1007/ s0028400101170.

Koronis S, Pizatos E, Polyzois G, Lagouvardos P. 2012. Clinical evaluation of three denture cushion adhesives by complete denture wearers. Gerodontology. 29:e161-169. doi: 10.1111/j.1741-2358.2010.436.x.

Kuhn DM, Balkis M, Chandra J, Mukherjee PK, Ghannoum MA. 2003. Uses and limitations of the XTT assay in studies of Candida growth and metabolism. J Clin Microbiol. 41:506-508. doi: 10.1128/JCM.41.1.506-508.2003.

Kuhn DM, Chandra J, Mukherjee PK, Ghannoum MA. 2002a. Comparison of biofilms formed by Candida albicans and Candida parapsilosis on bioprosthetic surfaces. Infect Immun. 70:878-888. doi: 10.1128/IAI.70.2.878-888.2002.

Kuhn DM, George T, Chandra J, Mukherjee PK, Ghannoum MA. 2002b. Antifungal susceptibility of Candida biofilms: unique efficacy of amphotericin B lipid formulations and echinocandins. Antimicrob Agents Chemother. 46:17731780. doi: 10.1128/AAC.46.6.1773-1780.2002.

Kulak Y, Ozcan M, Arikan A. 2005. Subjective assessment by patients of the efficiency of two denture adhesive pastes. J Prosthodont. 14:248-252. doi: 10.1111/jopr.2005.14.issue-4.

Kumamoto CA. 2002. Candida biofilms. Curr Opin Microbiol. 5:608-611. doi: 10.1016/S1369-5274(02)00371-5.

Kumar S, Pandey AK. 2013. Chemistry and biological activities of flavonoids: an overview. Sci World J. 2013:162750.

Labsi M, Khelifi L, Mezioug D, Soufli I, Touil-Boukoffa C. 2016. Antihydatic and immunomodulatory effects of Punica granatum peel aqueous extract in a murine model of echinococcosis. Asian Pac J Trop Med. 9:211-220. doi: 10.1016/j.apjtm.2016.01.038.

Lima JF, Maciel JG, Hotta J, Vizoto AC, Honorio HM, Urban VM, Neppelenbroek KH. 2016. Porosity of temporary denture soft liners containing antifungal agents. J Appl Oral Sci. 24:453-461. doi: 10.1590/1678-775720160092.

Liu RH. 2013. Health-promoting components of fruits and vegetables in the diet. Adv Nutr. 4:384S-392S. doi: 10.1016/ S0031-9422(96)00543-2.

Llabot JM, Palma SD, Manzo RH, Allemandi DA. 2007a. Design of novel antifungal mucoadhesive films Part I. Preformulation studies. Int J Pharm. 330:54-60.

Llabot JM, Palma SD, Manzo RH, Allemandi DA. 2007b. Design of novel antifungal mucoadhesive films. Part II. Formulation and in vitro biopharmaceutical evaluation. Int J Pharm. 336:263-268. doi: 10.1016/j.ijpharm.2006.12.001.

Loster JE, Wieczorek A, Loster BW. 2016. Correlation between age and gender in Candida species infections of complete denture wearers: a retrospective analysis. Clin Interv Aging. 11:1707-1714. doi: 10.2147/CIA.

Mansourian A, Boojarpour N, Ashnagar S, Momen Beitollahi J, Shamshiri AR. 2014. The comparative study of antifungal activity of Syzygium aromaticum, Punica granatum and 
nystatin on Candida albicans; an in vitro study. J Mycol Med. 24:e163-168. doi: 10.1016/j.mycmed.2014.07.001.

Neppelenbroek KH, Pavarina AC, Vergani CE, Giampaolo ET. 2005. Hardness of heat-polymerized acrylic resins after disinfection and long-term water immersion. J Prosthet Dent. 93:171-176. doi: 10.1016/j.prosdent.2004.10.020.

Ng SM, Yap YY, Cheong JW, Ng FM, Lau QY, Barkham T, Teo JW, Hill J, Chia CS. 2017. Antifungal peptides: a potential new class of antifungals for treating vulvovaginal candidiasis caused by fluconazole-resistant Candida albicans. J Pept Sci. 23:215-221. doi: 10.1002/psc.2970.

Papadiochou S, Emmanouil I, Papadiochos I. 2015. Denture adhesives: a systematic review. J Prosthet Dent. 113(391397):e392.

Park KD, Kim YS, Han DK, Kim YH, Lee EH, Suh H, Choi KS. 1998. Bacterial adhesion on PEG modified polyurethane surfaces. Biomaterials. 19:851-859. doi: 10.1016/S01429612(97)00245-7.

Peralta MA, da Silva MA, Ortega MG, Cabrera JL, Paraje MG. 2015. Antifungal activity of a prenylated flavonoid from Dalea elegans against Candida albicans biofilms. Phytomedicine. 22:975-980. doi: 10.1016/j.phymed.2015.07.003.

Perez P, Kapur KK, Garrett NR. 1985. Studies of biologic parameters for denture design. Part III: effects of occlusal adjustment, base retention, and fit on masseter muscle activity and masticatory performance. J Prosthet Dent. 53:69-73. doi: 10.1016/0022-3913(85)90069-1.

Pierce CG, Uppuluri P, Tristan AR, Wormley FL Jr, Mowat E, Ramage G, Lopez-Ribot JL. 2008. A simple and reproducible 96-well plate-based method for the formation of fungal biofilms and its application to antifungal susceptibility testing. Nat Protoc. 3:1494-1500. doi: 10.1038/ nprot.2008.141.

Pradies G, Sanz I, Evans O, Martnez F, Sanz M. 2009. Clinical study comparing the efficacy of two denture adhesives in complete denture patients. Int J Prosthodont. 22:361-367.

Samaranayake LP, McCourtie J, MacFarlane TW. 1980. Factors affecting the in-vitro adherence of Candida albicans to acrylic surfaces. Arch Oral Biol. 25:611-615. doi: 10.1016/00039969(80)90076-X.

Samet N, Laurent C, Susarla SM, Samet-Rubinsteen N. 2007. The effect of bee propolis on recurrent aphthous stomatitis: a pilot study. Clin Oral Investig. 11:143-147. doi: 10.1007/ s00784-006-0090-z.

Sato Y, Kaiba Y, Hayakawa I. 2008. Evaluation of denture retention and ease of removal from oral mucosa on a new gel-type denture adhesive. Nihon Hotetsu Shika Gakkai Zasshi. 52:175-182. doi: 10.2186/jjps.52.175.
Silva MJ, de Oliveira DG, Marcillo OO, Neppelenbroek KH, Lara VS, Porto VC. 2016. Effect of denture-coating composite on Candida albicans biofilm and surface degradation after disinfection protocol. Int Dent J. 66:86-92. doi: 10.1111/ idj.2016.66.issue-2.

Singh K, Shekhar S, Yadav Y, Xess I, Dey S. 2017. DS6: anticandidal, antibiofilm peptide against Candida tropicalis and exhibit synergy with commercial drug. J Pept Sci. 23:228-235. doi: 10.1002/psc.2973.

Tarbet WJ, Boone M, Schmidt NF. 1980. Effect of a denture adhesive on complete denture dislodgement during mastication. J Prosthet Dent. 44:374-378. doi: 10.1016/00223913(80)90092-X.

Terrell CL. 1999. Antifungal agents. Part II. The azoles Mayo Clin Proc. 74:78-100. doi: 10.4065/74.1.78.

Tobudic S, Lassnigg A, Kratzer C, Graninger W, Presterl E. 2010. Antifungal activity of amphotericin B, caspofungin and posaconazole on Candida albicans biofilms in intermediate and mature development phases. Mycoses. 53:208-214. doi: 10.1111/myc.2010.53.issue-3.

Varlam DE, Siddiq MM, Parton LA, Russmann H. 2001. Apoptosis contributes to amphotericin B-induced nephrotoxicity. Antimicrob Agents Chemother. 45:679-685. doi: 10.1128/AAC.45.3.679-685.2001.

Vasconcelos LC, Sampaio FC, Sampaio MC, Pereira Mdo S, Higino JS, Peixoto MH. 2006. Minimum inhibitory concentration of adherence of Punica granatum Linn (pomegranate) gel against S. mutans, S. mitis and $C$. albicans. Braz Dent J. 17:223-227. doi: 10.1590/S010364402006000300009.

Vidal A, Fallarero A, Pena BR, Medina ME, Gra B, Rivera F, Gutierrez Y, Vuorela PM. 2003. Studies on the toxicity of Punica granatum L. (Punicaceae) whole fruit extracts. J Ethnopharmacol. 89:295-300. doi: 10.1016/j. jep.2003.09.001.

Xu LC, Siedlecki CA. 2012. Submicron-textured biomaterial surface reduces staphylococcal bacterial adhesion and biofilm formation. Acta Biomater. 8:72-81. doi: 10.1016/j. actbio.2011.08.009.

Xu LC, Siedlecki CA. 2014. Staphylococcus epidermidis adhesion on hydrophobic and hydrophilic textured biomaterial surfaces. Biomed Mater. 9:035003. doi: 10.1088/17486041/9/3/035003.

Xu LC, Siedlecki CA. 2017. Protein adsorption, platelet adhesion, and bacterial adhesion to polyethylene-glycoltextured polyurethane biomaterial surfaces. J Biomed Mater Res B Appl Biomater. 105:668-678. doi: 10.1002/ jbm.b.v105.3. 